\title{
Structural Contingencies: Capitalist Constraints and Historical Contingency in the Rise and Fall of Pensions
}

\author{
Michael McCarthy, Marquette University
}

\begin{abstract}
After World War II, collectively bargained private pensions were installed as an alternative to Social Security expansions. But these plans began to go into decline in the 1980s, when defined-contribution retirement accounts, such as $401(\mathrm{k}) \mathrm{s}$, came to replace them. This article makes three arguments about this rise and fall to contribute toward a theory of structural contingency. First, in both episodes, state intervention into labor-management relations triggered policy changes in the private pension system. Second, policy makers were motivated to intervene because of a structural condition-namely, to manage perceived crises in capitalism. And third, the particular way they intervened and how their policy choices spurred pension marketization were driven by contingent historical circumstances. This article argues that structural constraints that inhere in capitalist democracies established a range of possible policy options available to policy makers, yet contingent and historical factors channeled policy selection within that range.
\end{abstract}

A merica has the largest private retirement security system in the world with 45.1 percent of retirement income in the United States derived from occupational pensions or employer-sponsored retirement plans. The Organization for Economic Cooperation and Development (OECD) average is just

This article draws from and expands on research and findings in my book Dismantling Solidarity: Capitalist Politics and American Pensions since the New Deal (Ithaca, NY: Cornell University Press, 2017). William H. Sewell Jr.'s comments, along with those of the reviewers, were central to this article's most recent developments. In its earlier stages it benefited from comments from Jonah Birch, Noelle Brigden, Anthony Chen, Mark Cohen, Barry Eidlin, Kevan Harris, Jeff Goodwin, Monica Prasad, Jessica Rich, and Adaner Usmani.

Critical Historical Studies (Spring 2019). @ 2019 by The University of Chicago. All rights reserved. 2326-4462/2019/0601-0003\$10.00 
19.5 percent. ${ }^{1}$ And although Social Security is the largest income-maintenance program in the United States, in relative terms it is smaller than the public pension programs in most other advanced capitalist countries. The gross preretirement earnings replacement rate in the United States is 42.3 percent for the average wage earner whereas the OECD average is 60.6 percent. In the United States, the labor market performance of workers going into retirement is the critical determining factor for their retirement security.

Furthermore, as pressures on retirement income have increased, retirement itself is becoming an increasingly fleeting stage in life for many ordinary Americans. In the United States, more than 35 percent of the income of people older than 65 comes from either employment income or self-employment. The OECD average is about 24 percent. $^{2}$ In the United States, 32 percent of people aged 65-69 work at either full- or part-time jobs. The only other countries in the OECD with a larger ratio of workers aged 65-69 are Iceland (53 percent), New Zealand (42 percent), Japan (42 percent), Israel (39 percent), Korea (46 percent), Chile (40 percent), and Mexico (39 percent). ${ }^{3}$

The key to understanding the situation of American old-age security today is found in the rise and fall of pensions. Traditional, defined-benefit (DB) occupational plans came to prominence and spread in the decades after World War II as an alternative to expansions in the public system. However, DB plans waned in the 1970s and 1980s and were replaced in the American economy with much riskier defined-contribution (DC) plans, such as $401(\mathrm{k})$ s. Both policy changes ushered in market-oriented arrangements and mechanisms of income distribution when more solidaristic ones that promised more equity and inclusion were on the table. The United States, in this regard, was on the leading edge of retirement marketization in the advanced capitalist world. During the same period, more solidaristic arrangements were being embraced by most other advanced capitalist democracies. ${ }^{4}$

Retirement plans, much like social policies more generally, can be organized in more or less solidaristic or market-oriented ways. ${ }^{5}$ Solidaristic programs pool social

1. OECD, Pensions at a Glance 2009: Retirement-Income Systems in OECD Countries (Paris: OECD, 2009).

2. OECD, Pensions at a Glance 2017: OECD and G20 Indicators (Paris: OECD, 2017), 133.

3. Ibid., 125.

4. Peter H. Lindert, Growing Public: Social Spending and Economic Growth since the Eighteenth Century (Cambridge: Cambridge University Press, 2004).

5. T. H. Marshall, Citizenship and Social Class, and Other Essays (New York: Cambridge University Press, 1950); Richard Titmuss, Essays on the "Welfare State," 2nd ed. (London: Allen \& Unwin, 1966). Private benefits are interwoven with state regulation; Christopher Howard, The Hidden Welfare State: Tax Expenditures and Social Policy in the United States (Princeton, NJ: Princeton University Press, 1997); Jacob S. Hacker, The Divided Welfare State (Cambridge: Cambridge University Press, 2002). But the public/private distinction remains a key way to understand welfare policies in spite of evidence that raises doubt about a sharp state 
risks (e.g., illness, poverty, and the inability to work in old age) across the population. In Peter Baldwin's useful phrase, "the terms of misfortune's reapportionment" do not rest on the individual but are collectively shared. ${ }^{6}$ In market-oriented programs, the ability of individuals to confront social uncertainties with success is a result of their own market performance rather than some larger social compact guided by the principle of mutual care.

More concretely, the most solidaristic public programs are universal, available to the entire population without conditions and equally distributed. Yet not all public, state-administered social programs are alike. They may also be targeted, available only to certain individuals who meet certain criteria often through means testing. Access and distribution in a targeted program are more greatly driven by a person's performance on the market. Similarly, employer-administered programs can be more or less market oriented. Some employer-provided plans cover all employees and are organized through a collective contract, bargained between a union and a firm or employers' association. Although less solidaristic than public universal plans, collective contract plans distribute risk across a larger pool of individuals than programs that allot benefits on the exclusive basis of the beneficiary's performance. In this latter type of program, the sole determinant of access and distribution is the beneficiary's performance on the labor market. Table 1 offers a visual summary of this typology. The arrows indicate a shift toward marketization between the program types.

Through this descriptive lens, this article shows that the development of old-age security in America since the New Deal cannot be understood primarily as the making of either a public or private approach. Nor can we think of it as primarily the making of a public-private mix, as most recent scholars do. ${ }^{7}$ Although the New Deal

versus market (or public versus private) distinction; Fred Block and Margaret R. Somers, The Power of Market Fundamentalism: Karl Polanyi's Critique (Cambridge, MA: Harvard University Press, 2014); Greta R. Krippner, "The Elusive Market: Embeddedness and the Paradigm of Economic Sociology," Theory and Society 30 (2001): 775-810. On the one hand, if a program is public or private does matter for how its provisions will be distributed. Employer-provided programs like private pensions are more likely to be voluntary, available on the basis of the firm's ability to pay for them, and inegalitarian because they tend to be provided for better-paid workers; Hacker, Divided Welfare State, 34-40. But on the other hand, conceptualizing welfare policy in solely public or private terms imposes strong limits on how scholars conceptualize social support. There is deep variation between and within both publicly and privately administered social programs, which can be thought of as differences in degree rather than kind.

6. Peter Baldwin, The Politics of Social Solidarity: Class Bases of the European Welfare State, 1875-1975 (Cambridge: Cambridge University Press, 1990), 2.

7. Marie Gottschalk, The Shadow Welfare State (Ithaca, NY: Cornell University Press, 2000); Hacker, Divided Welfare State; Jennifer Klein, For All These Rights: Business, Labor, and the Shaping of America's PrivatePublic Welfare State (Princeton, NJ: Princeton University Press, 2003). 
Table 1. Degrees of Marketization in Hypothetical Social Programs

\begin{tabular}{lcc}
\hline & Risk Sharing & Risk Individualized \\
\hline Publicly administered & $\begin{array}{c}\text { Universal } \\
\text { (most solidaristic) } \\
\text { Privately administered }\end{array}$ & $\begin{array}{c}\text { Collective contractual } \\
\text { (most market oriented) }\end{array}$ \\
\hline
\end{tabular}

offered the promise of a solidaristic approach to old-age income provisioning, in the decades that followed the retirement system went down several paths of marketization that increasingly individualized risk and tied retirement income to the worker's performance on capitalist labor markets. The rise and fall of traditional pensions in America shows that America's private pensioning system has become more marketized over time.

Three interdependent factors enabled the marketization of retirement security between the New Deal and the 1990s. First, both Democratic and Republican policymaker decisions to intervene in America's system of industrial relations triggered each market-oriented shift. Pension marketization was driven by a stronger hand of the state in labor-management affairs, not a weaker one as we might assume. Second, politicians intervened in the pension system to manage the broader market forces at work in the economy. Capitalist crises motivated politicians to act for capitalism generally, rather than solely at the behest of a particular interest group or in response to institutional constraints, to facilitate accumulation and to either maintain America's position in the world economy or anticipate geopolitical opportunities for capitalist growth. Third, both the form that policy interventions took and how the intervention itself drove marketization were shaped by contingent historical factors within both junctures. Although the structural need to promote capitalist growth limited options, contingencies pushed policy makers to select a particular path from within these options.

What explains the rise and spread of private pensions? Policy makers were confronted with the "reconversion dilemma" at the end of the war, which raised the difficult problem of converting the wartime economy to a peacetime economy without triggering more labor unrest. Wartime conditions ensured some labor peace and high levels of production. But as soon as the war ended and wartime agencies were lifted, industrial unrest and labor stoppages shut down industry. To take advantage of growth opportunities abroad policy makers needed to get production back on line and to regularize labor-management relations. There were potentially many ways to do this. As Mark Blyth observes, “structures don't come with an instruction 
sheet." ${ }^{8}$ How the Truman administration decided to intervene was shaped by the Democratic Party's unique relationship with labor at the time. Needing union electoral machines, Truman intervened in support of labor demands for collectively bargained pension plans and as a result helped to establish them as a supplement to Social Security. Labor's role in the Democratic Party helps to explain why Truman intervened in the way he did but not why he intervened in the first place.

In the fall of these traditional pension plans and the rise of $401(\mathrm{k}) \mathrm{s}$, policy makers were confronted once again with a crisis of capitalism in the 1970s-namely, stagflation. The OECD and members of the Federal Reserve circulated the view that labor unions were the primary cause and that employers needed to be pushed to squeeze wages. When Ronald Reagan was elected in 1980, he and Paul Volcker in the Federal Reserve made this one of their main economic priorities. Although the Reagan administration weakened unions in a number of ways, one way was to ratchet up regulations on traditional pension funds-some unions with wellpaid, middle-class members like the Teamsters had gained substantial control over their funds and used them as a source of bargaining power. Yet this intervention had the inadvertent effect of spurring on the rise of 401 (k)s. Union density was declining and regulations increased the administrative costs for employers operating a traditional pension plan. As a result, employers in new sectors of the economy that tended to also be nonunion increasingly adopted $40 \mathrm{l}(\mathrm{k})$ plans as an alternative to the traditional plans that were the norm. In this second episode, the need to manage capitalism again explains why policy makers intervened in the first place.

\section{HISTORICAL AND STRUCTURAL CONTEXTS OF POLICY CHANGE}

The view I give in this article cuts against the common account in the historiography. With respect to the installment and spread of traditional plans, according to the standard view, policy interventions in the 1940s and early 1950s laid the groundwork for the private pension system and locked its growth in place by what Marie Gottschalk has called an "institutional straightjacket." ${ }^{\prime 9}$ In the most popular account of the devel-

8. Mark Blyth, "Structures Don't Come with an Instruction Sheet," Perspectives on Politics 1, no. 4 (2003): 695-706.

9. Gottschalk, Shadow Welfare State, 39; see also Daniel Béland and Jacob S. Hacker, "Ideas, Private Institutions and American State 'Exceptionalism': The Case of Health and Old-Age Insurance, 1915-1965," International Journal of Social Welfare 13 (2004): 42-54; Daniel Béland, Social Security (Lawrence: University Press of Kansas, 2005); Howard, Hidden Welfare State; Hugh Macaulay, Fringe Benefits and Their Federal Tax Treatment (New York: Columbia University Press, 1959); Raymond Munts, Bargaining for Health: Labor Unions, Health Insurance, and Medical Care (Madison: University of Wisconsin Press, 1967); Beth Stevens, "Blurring the Boundaries: How the Federal Government Has Influenced Welfare Benefits in the Private Sec- 
opment of the pension system in the United States, Jacob Hacker uses the concept of path dependency to argue that policy feedbacks created lock-in effects in the process of pension privatization. ${ }^{10}$ Installing the private pension system after World War II created vested interests that in combination with the lower visibility of the policy making associated with the public program made private pensions "highly resistant to change" and ensured that the two-tier public-private system was "increasingly embedded" in the American approach to old-age security. ${ }^{11}$ Furthermore, Jennifer Klein's important history of the public-private welfare state similarly argues that early state decisions drove later changes even in the 1950s when policy makers withdrew, deferring to firms and insurance companies. ${ }^{12}$

Popular explanations for the eclipse of traditional plans and the adoption of DC plans, like 401 (k)s, follow a similar logic. Hacker argues that "two overarching trends" explain the rise of 401 (k)s: the unwillingness of policy makers to reconsider the public-private system installed after World War II and "a resurgent conservative strain in American politics." ${ }^{13}$ First, throughout the 1970s and 1980s, Congress preserved virtually all of the tax advantages (with some exception to individual retirement accounts) that it had established for occupational pension plans, leaving untouched the privatization path that the retirement system was already on. Second, Hacker notes that the "overall thrust of policy" was "in a more conservative direction" and helped usher in an even more privatized system with the DC plan. ${ }^{14}$ Section 401 (k) was famously included in the Revenue Act of 1978 with little controversy or fanfare, a form of subterranean politics "completely beneath the radar screen of public debate." ${ }^{15}$ But Hacker argues that when Ted Benna pressed the "Reagan IRS" to rule that the code could be extended to workers' employer retirement plans in 1981, it agreed, where more left-leaning administrations, we assume, might not. Whether the conservative interest in these tax-favored retirement accounts was part of an effort to achieve Social Security reform, as advocated by Stuart Butler and Peter Germanis in their 1983 Cato paper that laid out a "Leninist strategy" to undermine the public plan, or if conservatives just preferred them for cost and flexibility, Hacker argues that this partisan shift in the 1980s explains their adoption.

tor," The Politics of Social Policy in the United States, ed. Margaret Weir, Ann Shola Orloff, and Theda Skocpol (Princeton, NJ: Princeton University Press, 1988).

10. Hacker, Divided Welfare State.

11. Ibid., 83 .

12. Klein, For All These Rights.

13. Hacker, Divided Welfare State, 159, 163.

14. Ibid., 163.

15. Ibid., 165. 
In both their rise and fall, common accounts of America's pension system argue that the policy change was entirely political and a result of historical contingencies.

This historiography is largely institutionalist in its theoretical orientation. ${ }^{16}$ Institutionalists prioritize the state as the locus of change. ${ }^{17}$ They consider how the persistent features of the constitutional system combine with the properties of the governing bodies to shape the outcomes of politics as they unfold in time. ${ }^{18}$ And they explore how policy making paths persist by showing how state policies create incentive structures for policy makers and how political settlements between competing groups can have long-lasting effects on institutional change itself. ${ }^{19}$

But by rendering the capitalist context in which policy making and institutions are embedded invisible, institutionalism offers only a partial view of history. Institutionalists curiously allude to this in their own work but often just in passing. Hacker refers to the "tectonic shifts in the American economy" that proceeded the erosion of traditional pension plans and the rise of $40 \mathrm{l}(\mathrm{k}) \mathrm{s}$, factors like "the stagnation of real wages, the decline of organized labor, the movement of employment from manufacturing to services." ${ }^{20}$ Yet strangely these are not explored as actual causes and remain

16. By institutions, these scholars do not mean social conventions in the sense that has been used in classical social theory; see Richard Swedberg, "Max Weber's Vision of Economic Sociology," Journal of Socio-Economics 27 (1998): 535-55. Much of the sociological study of institutions treats them as systems of shared beliefs, norms, and collective sentiments. For instance, Nee defines institutions as "a dominant system of interrelated informal and formal elements—custom, shared belief, conventions, norms, and ruleswhich actors orient their actions to when they pursue their interests"; see Victor Nee, "The New Institutionalism in Economics and Sociology," in The Handbook of Economic Sociology, ed. Neil Smelser and Richard Swedberg, 2nd ed. (Princeton, NJ: Princeton University Press, 2005), 55. Instead, the historical institutionalists limit themselves to formal institutions—defined as the codified rules of political contestation-and the individual rules that are nested within the general rules of political contestation, such as public and private policies; see Paul Pierson, Politics in Time (Princeton, NJ: Princeton University Press, 2004); Kathleen Thelen and Sven Steinmo, "Historical Institutionalism in Comparative Politics," in Structuring Politics: Historical Institutionalism in Comparative Analysis, ed. Sven Steinmo, Kathleen Thelen, and Frank Longstreth (Cambridge: Cambridge University Press, 1992), 1-32; Paul Pierson, Dismantling the Welfare State? Reagan, Thatcher and the Politics of Retrenchment (Cambridge: Cambridge University Press, 1994).

17. Theda Skocpol, Protecting Soldiers and Mothers: The Political Origins of Social Policy in the United States (Cambridge, MA: Harvard University Press, 1992); Ann Shola Orloff and Theda Skocpol, "Why Not Equal Protection? Explaining the Politics of Public Social Spending in Britain, 1900-1911, and the United States, 1880s-1920s," American Sociological Review 49 (1984): 726-50; Edwin Amenta, Bold Relief (Princeton, NJ: Princeton University Press, 1998), 24; Edwin Amenta, When Movements Matter (Princeton, NJ: Princeton University Press, 2006); Ellen Immergut, The Political Construction of Interests: National Health Insurance Politics in Switzerland, France and Sweden (New York: Cambridge University Press, 1992).

18. Pierson, Politics in Time; Adam Sheingate, “Institutional Dynamics and American Political Development," Annual Review of Political Science 17 (2014): 461-77.

19. Monica Prasad, The Politics of Free Markets: The Rise of Neoliberal Economic Policies in Britain, France, Germany, and the United States (Chicago: University of Chicago Press, 2006); James Mahoney and Kathleen Thelen, eds., Explaining Institutional Change: Ambiguity, Agency, and Power (Cambridge: Cambridge University Press, 2009).

20. Hacker, Divided Welfare State, 153. 
largely ignored in the historical account. Instead, they are referenced and passed over. $^{21}$

\section{STRUCTURE AND HISTORY}

The approach I develop builds on three neo-Marxist propositions that have largely fallen out of view in the history of pension systems. First and most fundamentally is that the capitalist context structures the decisions made by policy makers, and capitalist crises within it helps to explain the timing of each shift. The capitalist context is not a mere backdrop to politics. Instead, it imposes constraints on policy makers, pushing them away from certain policy paths and ushering them toward others. ${ }^{22}$ Second, a key driving force behind some instances of policy change are political interventions intended by policy makers to manage capitalist crises and accumulation by encouraging growth. And third, the politics of welfare state development need not be a result of straightforward partisan politics (e.g., one or another political party gaining or losing control of key state positions) or interest group politics (e.g., unions, business, or any other interest groups organizing around and winning their policy preferences).

Against the historical institutionalist view that holds policy makers' interests as more contingent, what explains their motivation to intervene to support capitalist accumulation? Policy makers are structurally compelled and will be oriented toward procapitalist policies even in the absence of the direct influence of business interest groups. ${ }^{23}$ Regardless of the partisanship or ideological commitments of the

21. Recently, leading institutionalists acknowledge this limitation in their theoretical frameworks, yet their accounts remain largely unrevised. See Jacob S. Hacker and Paul Pierson, "Business Power and Social Policy: Employers and the Formation of the American Welfare State," Politics e Society 30, no. 2 (2002): 277-325, and Winner-Take-All Politics: How Washington Made the Rich Richer-and Turned Its Back on the Middle Class (New York: Simon \& Schuster, 2010).

22. James O'Connor, The Fiscal Crisis of the State (1973; New Brunswick, NJ: Transaction, 2002); Claus Offe, Contradictions of the Welfare State (Cambridge, MA: MIT Press, 1984); Frances Fox Piven and Richard Cloward, Regulating the Poor: The Functions of Public Welfare (New York: Vintage, 1971).

23. Fred Block, "The Ruling Class Does Not Rule," Socialist Revolution 33 (1977): 6-28; Charles Lindblom, Politics and Markets: The World's Political Economic Systems (New York: Basic, 1977). A more interest-group approach to the power of capitalism in policy making is concerned with the ways that firms directly shape policy though their lobbyists, their recruitment into policy making positions, their campaign contributions, and their privileged access to policy makers. But in surveying the archival record on pension change, I did not find that politicians were working at the behest of individual businesses, sectors, or associations. What stood out in congressional debates and personal correspondences was that they were compelled to intervene for capitalism broadly rather than particular capitalists. See C. Wright Mills, The Power Elite (Oxford: Oxford University Press, 1956); G. William Domhoff, Who Rules America? (Upper Saddle River, NJ: Prentice Hall, 1967); Ralph Miliband, The State in Capitalist Society (New York: Basic, 1969); Dan Clawson, Alan Neustadtl, and Mark Weller, Dollars and Votes: How Business Campaign Contributions Subvert Democracy (Philadelphia: Temple University Press, 1998). 
governing party or coalition, policy makers have a professional interest in promoting policies that facilitate firm investment and growth. ${ }^{24}$ When policy makers fail to promote a healthy "investment climate" and "business confidence," they face professional costs if businesses decide to disinvest. ${ }^{25}$ In the event that policy makers too deeply undermine the rate of profit of firms, business structural power can take the form of "capital strikes." 26 The power of firms to disinvest from economic activity when policy threatens to undermine profit is a structural constraint that encourages policy makers to create and maintain favorable conditions for business regardless of who is in office. ${ }^{27}$

But much life remains in historical institutionalism. At heart, structural constraints establish a range of possible policy options available to policy makers, whereas contingent and historical factors explain the selection within that range. I offer two provisos that reformulate neo-Marxist theories to illustrate this relationship. First, neo-Marxist theories of policy change were articulated at too high a level of conceptual abstraction to account for the contingent historical conditions that mattered to how politicians intervened in America's private retirement system since the New Deal period. Thus, an element of historical institutionalism's emphasis on contin-

24. Nicos Poulantzas, "The Problem of the Capitalist State," New Left Review 58 (1969); Nicos Poulantzas, State, Power, Socialism (London: New Left Books, 1978); Pepper D. Culpepper and Raphael Reinke, "Structural Power and Bank Bailouts in the United Kingdom and the United States," Politics $\theta$ Society 42 (2014): 427-54; Thomas Paster, "Bringing Power Back In: A Review of the Literature on the Role of Business in Welfare State Politics" (Max-Planck Institute for the Study of Societies Discussion Paper 15/3, 2015).

25. Block, "Ruling Class," 16; Adam Przeworski and Michael Wallerstein, "Structural Dependence of the State on Capital," American Political Science Review 82 (1988): 11-29; Duane Swank, "Politics and the Structural Dependence of the State in Democratic Capitalist Nations," American Political Science Review 86 (1992): 38-54. As Fred Block ("Ruling Class,") writes, "business confidence is . . very different from 'rulingclass consciousness.' Business confidence is based on an evaluation of the market that considers political events only as they might impinge on the market. This means that it is rooted in the narrow self-interest of the individual capitalist who is worried about profits" (16).

26. There are two unique ways that disinvestment hurts policy makers. First, states are deeply dependent on firms for tax revenues. In the case that the economy takes a turn for the worse, states will be forced to draw out less tax revenue from firms' profits and workers' income, undermining their capacity to govern. Second, if capitalists disinvest and the economy goes into a downturn, people will lose their jobs. Policy makers are dependent on voters for legitimacy when they govern for capitalist growth. Without work, those hardest hit by the downturn will have a reason to vote policy makers out of office during the next election cycle in favor of a candidate they think will better encourage job growth; see Joshua Cohen and Joel Rogers, On Democracy: Toward a Transformation of American Society (New York: Penguin, 1983); Wolfgang Streeck, Buying Time: The Delayed Crisis of Democratic Capitalism (London: Verso, 2013).

27. Charles Lindblom ("The Market as Prison," Journal of Politics 44 [1982]) calls this process the "automatic punishing recoil" (325), and Claus Offe ("The Capitalist State and the Problem of Policy Formation," in Stress and Contradiction in Contemporary Capitalism, ed. Leon Lindberg et al. [Lexington, MA: D. C. Heath, 1975]) refers to firm disinvestment as "negative events" (133). As Offe writes, "the basic prerogative of free enterprises is a negative one: the right not to produce unless production is at the same time accumulative, that is, not only production of useful things but simultaneously production of surplus value, or profit" (126). 
gency must be retained. Often neo-Marxists sought to offer covering laws, akin to the industrialization theories that they were in conversation with, which were concerned with the broad relationship between economic growth and welfare development. ${ }^{28}$ Claus Offe, for instance, suggests there are "laws of motion" of the development of social policy akin to the economic laws that Marx sought to uncover in the capitalist economy. ${ }^{29}$ But policy change in the case of American pensions is not so mechanistic.

Second, neo-Marxists made functionalist arguments about welfare change, too tightly coupling the effect of a policy with some need of capitalism. But social systems do not have needs; the people in those systems do. Instead of investigating the actors involved, the dynamics of welfare development, within this mode of reasoning, are explained in terms of the functional requirements of reproducing the system of capitalism itself. As James O'Connor writes, capitalism is a “self-correcting system" and "poverty and government relief are . . inherent features of capitalist development." ${ }^{30}$ But pension marketization often served no functional need for capitalism itself. If it did, in most cases it was not even recognized as such by the individuals and interests that actively made it because, empirically speaking, the intentions of policy makers in earlier crisis theories of the welfare state were often insufficiently taken into account. Changes in America's retirement security system were rarely the reason for the political interventions that caused them, and in some instances the change was unintended altogether. Against a neat functionalist view of policy change, pensions were often far from the minds of policy makers when they intervened and hardly considered by them essential to the growth of the American economy.

\section{EXPLAINING THE RISE AND FALL OF PENSIONS IN AMERICA}

\section{EPISODE 1: POSTWAR PENSION EXPANSION, 1945-1960}

After expansions to Social Security in the 1939 amendments, the program stagnated into the late 1960s. Although amendments to the Social Security Act in 1950 and 1954 moved the public system toward universality in coverage, it never came close to being an adequate retirement income on its own. The next time Social Security replacement rates were expanded beyond correcting for inflation was under the

28. Clark Kerr, John T. Dunlop, Frederick Harbinson, and Charles A Meyers, Industrialism and Industrial Man (Oxford: Oxford University Press, 1964); Harold Wilensky, Industrial Society and Social Welfare (New York: Free Press, 1965).

29. Offe, Contradictions, 101.

30. O'Connor, Fiscal Crisis, 151, 158. 


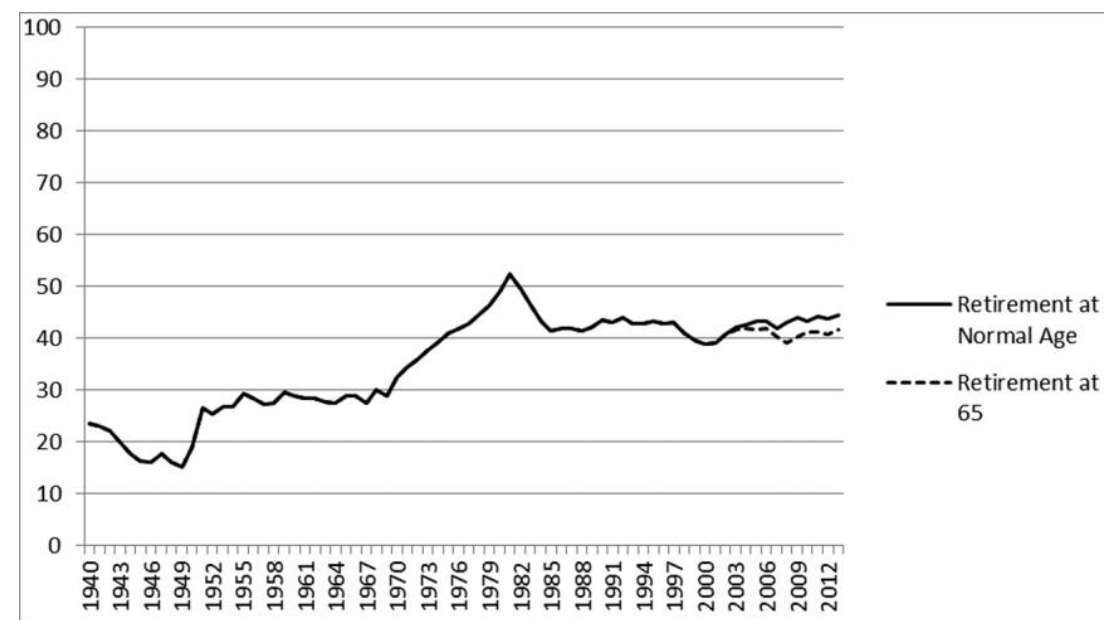

Figure 1. Social Security replacement rate median income earner, 1940-2013. Author's calculations from the US Social Security Administration, The 2013 Annual Report of the Board of Trustees of the Federal Old-Age and Survivors Insurance and Federal Disability Insurance Trust Fund (Washington, DC: Government Printing Office, 2013), table V.C7.

Republican presidency of Richard Nixon (fig. 1). Private pensions took a different course; the share of workers with a pension increased from 15 to 30 percent between 1940 and $1960 .{ }^{31}$ What explains this postwar spread of private pensions?

After World War II, policy makers were confronted with the reconversion dilemma: how to shift from a wartime economy to a peacetime economy. Institutionalist history overlooks this. During the war, large-scale coordination of private enterprises required high levels of labor productivity and a strictly enforced labor peace. The latter was largely established by two conditions. First, the top-level officials at the Congress of Industrial Organizations (CIO), with the initial exception of John L. Lewis of the United Mine Workers (UMW), took every measure to ensure these conditions were met. ${ }^{32}$ Unions coordinated active support for the state through the adoption of the wartime no-strike pledge, despite internal dissent from many of their own rank and file. ${ }^{33}$ Second, President Roosevelt responded to initial wartime labor unrest by creating the National Defense Mediation Board (it later became the National War Labor Board), an ad hoc state agency made with the explicit purpose of managing labor and management relations. The agency gave the president power

31. Hacker, Divided Welfare State, 79.

32. "A Program for Increasing WWII Production through Full Employment," submitted to the War Manpower Commission by Walter P. Reuther, UAW President's Collection: Walter P. Reuther, box 31, Walter Reuther Memorial Archive, Detroit (hereafter cited as UAWPC).

33. "Stop Collective Begging" and "Referendum Starts," box 32, "No Strike Pledge 1944" folder, UAWPC. 
to intervene in labor disputes in plants that were critical to the fighting effort abroad by, among other things, giving him the authority to seize control of them. During the course of the war, three production plants were seized by the government in this way. ${ }^{34}$

The no-strike pledge and wartime government agencies were lifted after the war. Unions, eager to recoup wage and benefit gains, led the largest strike wave in US history to that point. In the first year after the war there were more than 4,600 work stoppages involving about 120 million workers. War was a boon for American industrialists, but employers were keen on keeping postwar labor gains at a minimum and their right to manage shop floor issues secure. Just a month after Japan's surrender, 43,000 oil workers went on strike. The Oil Workers International Union pushed firms for pay increases but ended their strike, which cut the US oil supply by a third, in failure. Truman seized the mines and ran them with personnel from the navy. ${ }^{35}$ In many of the disputes that followed, Truman continued to force agreements between labor and management, promoting the adoption of collectively bargained pension plans.

There were several ideas about how to reestablish a labor peace circulating among policy makers; an alternative argued by Republicans and Southern Democrats was labor repression. The political need to ensure stable accumulation established a range of possible policy options. But historical contingencies of the sort institutionalists point to help explain which path was followed within that range. As I show later in this section, the electoral role of the CIO labor federation within the northern section of the Democratic Party was reason enough for Northern Democrats to support those union bargaining objectives that did not risk their primary postwar goal of encouraging capitalist accumulation.

From the perspective of policy makers, Truman's interventions into labor disputes were a means to solve the reconversion dilemma and had little to do with partisan interests in retirement issues. In November 1945, Truman laid out the problem to a large group of employers and labor representatives at the president's national labor-management conference in clear terms saying,

Our country is worried about our industrial relations. It has a right to be . . . You have it in your power to stop that worry. Under the pressure of a desperate war crisis, management and labor have performed a miracle of production for four years-working together voluntarily but under a measure of

34. Arthur F. McClure, The Truman Administration and the Problems of Postwar Labor, 1945-1948 (Rutherford, NJ: Farleigh Dickinson University Press, 1969), 27.

35. Ibid., 48. 
Government control. Those controls must soon disappear. Many have already gone. And yet as soon as the first ones were taken off, industrial strife appeared. Some of it was expected by the American people in this period of adjustment. But I am sure that they never expected anything like the amount of strife which has been threatened. ${ }^{36}$

An effort at voluntary cooperation, the president's conference ended in failure with unions and employers refusing to concede on important points of disagreement.

This failure represented nothing short of a crisis of capitalism for policy makers, both Democrat and Republican. They were poised to grab the "unprecedented opportunity" that American capital had in the markets of war-torn Europe, whose economic infrastructure had been totally shattered by falling bombs and violence. ${ }^{37}$ Again, Truman put this clearly at the labor-management conference:

The whole world now needs the produce of our mills and factories-everything stands ready and primed for a great future. But situations and circumstances can change rapidly. Our unparalleled opportunity may not long remain open. We must have production-vast production. We must have it soon. In order to have it, labor and management must work together to expand the economy of our Nation-as they worked together to protect the safety of our Nation during the war. If we get the production we needthe production which our resources and industrial skill make possible, the present problem of wages and prices will be easier to solve. Production means employment. It means economic health. It means higher wages and lower prices. It means the difference between strength and prosperity on the one hand, and uncertainty and depression on the other. ${ }^{38}$

Neither unions nor capitalists grabbed hold of this opportunity. Less than a month after the conference ended in failure, Truman returned to Congress, absolutely determined to restart the capitalist economy and get production back up. In his speech Truman again made clear his intentions, saying,

If industrial strife continues, the quick reconversion which has been planned, and which is now proceeding on schedule or even ahead of schedule on

36. Harry Truman, box 141, President's National Labor-Management Conference: General, November 5, 1945, "Labor-Management Conference Transcriptions Docs 1-64" folder, National Association of Manufacturers Collection subject files, Hagley Library, Wilmington, DE (hereafter cited as NAM Collection).

37. Leo Panitch and Sam Gindin, The Making of Global Capitalism: The Political Economy of American Empire (London: Verso, 2012), 89.

38. Harry Truman, box 141, "Labor-Management Conference Transcriptions Docs 1-64" folder, NAM Collection. 
many fronts, will fail. In that event, we should face a period of low production, low consumption, and widespread unemployment—instead of the high production, high employment, good markets and good wages that are within our grasp . . . Industrial strife in some key industries means not only loss of a great amount of wages and purchasing power; but it may have ramifications throughout the country affecting the whole reconversion process. In such industries, when labor and management cannot compose their differences, the public through the Federal Government has a duty to speak and act. ${ }^{39}$

In the coming months, policy makers forced capital's hand during contract settlements. Although their bargaining position was weakened by the fall in demand for wartime goods and by a flooding of the labor market by returning veterans, unions made a large-scale push for wages and fringe benefits. ${ }^{40}$ The UMW took the first initiative. Although the union had broken with the CIO in 1942 and severed ties with Roosevelt two years earlier, their efforts after the war set the stakes in the postwar bargaining disputes. In 1945, the UMW demanded an employerfinanced pension fund and wage gains but backed down in face of owner opposition. Mine workers' take-home pay had increased over the past few years, but that was solely due to working more hours-their rate of pay had not increased since $1941 .^{41}$ In the next year, Lewis called a nationwide strike. Mine workers shut down the industry on April 1, leading to shortages in coal that cut steel production in half, slowed down auto production in Detroit, led to an embargo on rail freight, and reduced passenger rail service by 25 percent. ${ }^{42}$

On May 21, a fed-up Truman invoked the War Labor Disputes Act with Executive Order No. 9728, authorizing Secretary of the Interior J. A. Krug to seize the mines and negotiate an agreement between the mine workers and the coal operators. ${ }^{43}$ By May 29, the operators and the union signed an agreement. Although he was no friend of Lewis, Truman's influence enabled the mine workers to establish a pathbreaking pension plan that included disaster, medical, death, disability,

39. Harry Truman, Message to Congress, December 32, 1945, US Chamber of Commerce Collection, series 4, box 2, "President's National Labor-Management Conference: Reference Manual" folder, Hagley Library, Wilmington, DE (hereafter cited as USCOC).

40. US Bureau of Labor Statistics, "Employee Benefit Plans Under Collective Bargaining," Bulletin No. 946 (1948): 5 .

41. McClure, Truman Administration, 143.

42. Melvyn Dubofsky and Warren van Tine, John L. Lewis: A Biography, abridged ed. (Champaign: University of Illinois Press, 1986), 331.

43. After the president first seized the mines, Lewis famously remarked, "Let Truman dig coal with his bayonets"; Robert J. Donovan, Conflict and Crisis: The Presidency of Harry S. Truman, 1945-1948 (New York: Norton, 1977), 240. 
and survivor annuity insurance. In addition, the retirement plan paid a flat rate of $\$ 100$ a month that, in combination with public pension benefits, provided a livable retirement. ${ }^{44}$ The contract included two separate welfare funds. First, a health and welfare fund was financed by a tax on the industry payroll. And a second fund, which gave the union sole control of administration, was financed by company deposits deducted from the miner's wages. ${ }^{45}$

Large-scale strikes over pensions also erupted in the steel and auto industries in 1945, where CIO unions were organizing. ${ }^{46}$ Strikes resumed a few years later, after labor's initial defeat. The United Steel Workers first went out on strike. The White House formed the Steel Industry Board, which recommended that the owners agree to company-financed pensions. And on April 13, 1948, the presidentially appointed NLRB made a landmark decision. In accordance with the Taft-Hartley Act, the NLRB ruled that the Inland Steel Company was engaging in unfair labor practices when it refused to bargain with the United Steel Workers CIO regarding the terms of the pension plan and its retirement policy. Instead, it ordered the company to bargain with the union over pension policy, provided that the union qualified under the noncommunist and financial provisions of the law. ${ }^{47}$ The ruling determined that pensions "lie within the statutory scope of collective bargaining." ${ }^{48}$ The case was upheld by the United States Circuit Court of Appeals on September 23, 1948. And on April 25, 1949, the US Supreme Court set its stamp of approval on the ruling by refusing to review the decision. Like in steel, Ford and the United Auto Workers (UAW) ended in a deadlock in 1948 over the issue of pensions. The company had refused and the union was forced to settle. ${ }^{49}$ However, during negotiations in the following year over the same issues, the report issued by the Steel Industry Board drastically shifted the momentum in favor of the autoworkers. Shortly after, Ford and the UAW signed a Memorandum of Agreement on Retirement and Health Security Programs based on the Steel Industry Board's recommendations.

44. The United Mine Workers Journal deemed the contract "the greatest economic and social gains registered by the UMWA in a single wage agreement since the birth of the union in 1890"; McClure, Truman Administration, 147.

45. Dubofsky and van Tine, John L. Lewis, 332.

46. "President's Labor-Management Conference 1945," series 4, box 2, "President's LaborManagement Conference" folder, USCOC.

47. National Industrial Conference Board, Pensions, Studies in Personnel Policy, no. 103 (New York: National Industrial Conference Board, 1950).

48. Steven Sass, The Promise of Private Pensions: The First Hundred Years (Cambridge, MA: Harvard University Press, 1997), 132.

49. "Agreement on Retirement Plan," box 99, "Ford Department Pension Plan" folder, UAWPC. 
These state interventions alongside the Supreme Court decision settled the question of pensions being subject to bargaining. ${ }^{50}$ And employers were forced to begrudgingly accept it. The National Association of Manufacturers, previously a staunch opponent, resigned itself to the position that "mandatory bargaining [over pensions] is now a fact." ${ }^{51}$ Capitalist resignation bears out in the statistical evidence concerning contract outcomes. According to a National Industrial Conference Board study of 487 contracts that were reopened in 1949 (covering 1.26 million workers), the decision had an immediate effect. ${ }^{52}$ Out of 399 signed before the steel fact-finding report of January l-September 9, 47.2 percent of renewed contracts made increases in fringe benefits (out of a set of contracts that covered 479,526 workers). After the report of September 10-December 31, 96.3 percent of the 88 renewed contracts (covering 593,162 workers) made increases in fringe benefits, and 93.1 percent made increases in fringe benefits alone. ${ }^{53}$

Truman and his administration could have taken many different policy paths to promote capitalist growth. The relatively pro-labor path they did take in contract disputes is largely explained by the electoral role labor played within the New Deal coalition. The CIO arose in 1935, in the midst of widespread industrial conflict, with UMW leader John L. Lewis acting as its main architect. The officials of the federation almost immediately adopted a pro-Democrat political stance. Roosevelt's famed Section 7(a), the so-called right to unionize clause in the National Industrial Recovery Act, earned him many close allies in the CIO's top ranks. ${ }^{54}$ Such was evident by the 1936 elections, during which the CIO formed Labor's Nonpartisan League to help secure his reelection. However, it was not until World War II that a pro-Democratic orientation became fully institutionalized into the CIO wing of the labor movement. The 1938 and 1942 elections, in which blocs of antilabor Republicans and Southern Democrats won seats in Congress, spurred CIO leaders to formulate a long-term political plan. After the elections, a top-level political action report within the federation asserted that there was no hope in influencing Republicans. Instead, the CIO should put its full resources behind the Democrats. ${ }^{55}$

50. National Industrial Conference Board, Pensions.

51. "Company-Established Employee Benefit Program Subcommittee," November 2, 1949, NAM Committee Records, box 154, “NAM Committee Minutes 1949 Nov.-Dec." folder, NAM Collection.

52. National Industrial Conference Board, Pensions, 10.

53. National Industrial Conference Board, What Happened in the 1949 Wage Negotiations, Studies in Personnel Policy, no. 105 (New York: National Industrial Conference Board, 1950).

54. Irving Bernstein, The Lean Years: A History of the American Worker, 1920-1933 (1969; Chicago: Haymarket, 2010).

55. James C. Foster, The Union Politic: The CIO Political Action Committee (Columbia: University of Missouri Press, 1975), 21. 
This stance was made official with the formation of the CIO Political Action Committee (CIO-PAC) in 1943, of which Sidney Hillman would take the helm until his death three years later. Outside the strongholds of the Democratic urban machines, the party lacked the organizational infrastructure to mobilize new urban populations to the polls. The CIO's organizing arm aimed to fill this gap. ${ }^{56}$ Although the first goal of the CIO-PAC was the reelection of Roosevelt in the 1944 elections, it remained an active organizing hub for Democratic candidates well into the 1950s. In his book The New Men of Power, C. Wright Mills went as far as describing it as "an appendage of the Democrats." ${ }^{57}$ Assuming that its more than 5 million members could secure victories in several congressional districts, the CIO-PAC made its main purpose the political education of the CIO membership to build a reliable and easily mobilized electoral constituency for the Democratic Party. ${ }^{58}$ American businesses recognized this strategy's "dangerous" potential. The National Association of Manufacturers lamented: "Organized labor has created a political missile of massive proportions." $^{59}$

In short, Truman supported organized labor because he and other Northern Democrats were reliant on its electoral support. The CIO-PAC made up a large campaign machine with regional offices in key northern cities. Under its direction, tens of thousands of local campaign workers mobilized CIO members and their communities to vote for Democratic candidates. If taken to the polls, CIO leaders believed that the growing corps of organized industrial labor could prove to be an effective electoral force. In the decades following the New Deal, this corps only grew. Both union density and the number of employees in unions tripled between 1936 and the end of World War II. ${ }^{60}$ Yet despite the CIO's enthusiasm for expanding both public and private pensions after the war, its electoral activity facilitated an expansion of the latter and not the former. Unions lacked the needed political capital. ${ }^{61}$

Many labor leaders understood these contract victories in just these terms. In the spring of 1946, the head of the Amalgamated Clothing Workers of America said

56. J. David Greenstone, Labor in American Politics (1969; Chicago: University of Chicago Press, 1977), 51.

57. C. Wright Mills, The New Men of Power (New York: Harcourt, Brace, \& World, 1948), 184.

58. Greenstone, Labor in American Politics.

59. National Association of Manufacturers, “Organized Labor's Program to Organize the Legislative Halls," box 432, UAWPC.

60. Author's calculations from US Bureau of Labor Statistics, "Handbook of Labor Statistics," Bulletin No. 2070 (1980), table 165, 412.

61. Michael A. McCarthy, Dismantling Solidarity: Capitalist Politics and American Pensions since the New Deal (Ithaca, NY: Cornell University Press, 2017). 
that the CIO had won its strikes by "political action" as well as economic action. ${ }^{62} \mathrm{In}$ the context of these strikes, as urban Democratic machines became less effective after the war, unions shored up their political activity. The American Federation of Labor founded the Labor's League for Political Education and together with the CIO-PAC spent more than \$2 million on Truman's 1948 reelection bid and fielded more than 250,000 campaign workers on Election Day. Truman himself understood just how critical labor was in his coalition. On the day after his surprising 1948 victory he explained, "Labor did it."63

Collectively bargained plans expanded rapidly until 1960; thereafter the pace of adoption considerably slowed. As a percentage of the workforce covered, DB pensions had reached their peak use in the late 1970s. In 1979, union membership was the single greatest predictor of access to a DB plan, as 80 percent of all union members participated in one. ${ }^{64}$ The share of workers, union and nonunion alike, participating in an employer retirement plan reached 45 percent by 1979 and remains at nearly the same ratio today, even if many of these workers are in $401(\mathrm{k})$, DC retirement schemes. ${ }^{65}$

EPISODE 2: FROM TRADITIONAL PLANS TO THE $401(\mathrm{~K})$,

$1970-1995$

By the late 1970s and early 1980s, the design of American old-age security was on the cusp of undergoing another great transformation. Gradually, DC plans, such as $401(\mathrm{k}) \mathrm{s}$, came to replace the traditional DB plans that labor unions had won after the war. This change brought costs for future retirees. DC plans, such as 401 (k)s, do not guarantee retirement benefit levels like their DBs do. Instead, in DCs the beneficiaries are responsible for making smart investment choices to create a nest egg large enough to adequately supplement the retirement income they earn from both Social Security and any personal savings they might have. The net effect of this shift to DC plans is to allocate even more risk to workers and less to the firms that sponsor the plans, resulting in generally lower replacement rates and greater volatility in retirement income. ${ }^{66}$

62. Jack Barbash, "Unions, Government, and Politics," Industrial and Labor Relations Review 1, no. 1 (1947): 69

63. Sean J. Savage, Truman and the Democratic Party (Lexington: University of Kentucky Press, 1997), 138.

64. Sass, Promise, 139.

65. Employee Benefit Research Institute, "What Are the Trends in Defined Benefit Pension Plans?," 2015, http://www.ebri.org/publications/benfaq/index.cfm?fa = retfaqtl4fig 1 .

66. Alicia H. Munnell and Annika Sundén, Coming Up Short: The Challenge of 401(k) Plans (Washington, DC: Brookings, 2004); Alicia H. Munnell, Anthony Webb, and Francesca Golub-Sass, The National Retirement Risk Index: An Update, Center for Retirement Research Issue Brief No. 12-20 (Boston: Boston College, 2012). 


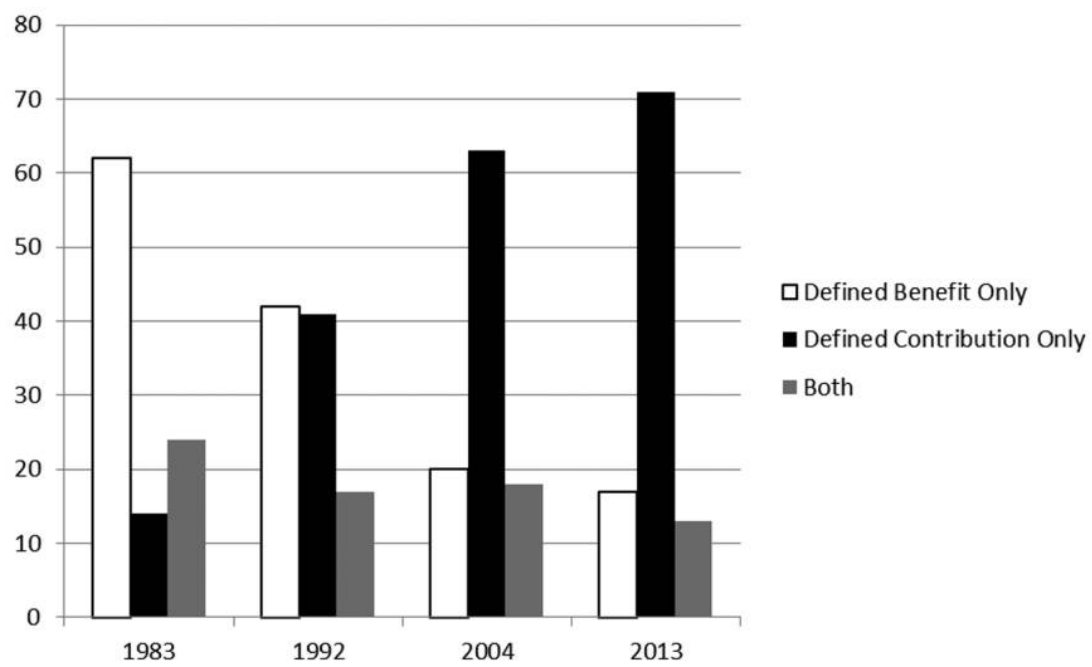

Figure 2. Percentage of workers with pension coverage by type of plan, 1983-2013. Author's calculations from Alicia H. Munnell and Annika Sundén, "401(k) Plans Are Still Coming Up Short" (Issue Brief no. 43, Center for Retirement Research, Chestnut Hill, MA, 2006); Charles D. Ellis, Alicia H. Munnell, and Andrew D. Eschtruth, Falling Short: The Coming Crisis and What To Do about It (Oxford: Oxford University Press, 2014).

Prior to the 1980s, DC plans were marginal within the pension system, typically reserved for higher-paid employees as a supplement to their traditional plans. In the 1980s, this arrangement rapidly broke down. By the early 1990s, the number of participants in DB and DC plans was evenly split and, by the 2000s, DC plans had clearly become the private retirement vehicle of choice for many American employers (see fig. 2). The 401 (k) is a type of DC plan. In the Revenue Act of 1978 they were named after a new section of the US Internal Revenue Code that concerns bonus payments for employers and were practically nonexistent before the Reagan era. They grew rapidly, however, during the 1980s and 1990s. In 1984, they represented just 3 percent of all private plans and 4 percent all DC plans. By 1998, those values were 41 percent and 45 percent, respectively. Similarly, as a percentage of all plan participants in both DB and DC plans, 401(k)s grew from 12 percent in 1984 to 51 percent in 1998. For just those participants in DC plans, $401(\mathrm{k}) \mathrm{s}$ grew from 25 percent in 1984 to 74 percent in 1998 and have become the industry standard for those firms that are willing to offer their employees a pension plan, pushing retirement income provisioning even further down the path of marketization. ${ }^{67}$

67. Employee Benefits Research Institute, An Evolving Pension System: Trends in Defined Benefit and Defined Contribution Plans, EBRI Issue Brief No. 249 (Washington, DC: Employee Benefits Research Institute, 2002). 
What explains this shift? Contrary to the historical institutionalist argument that $401(\mathrm{k}) \mathrm{s}$ were a path-dependent feature of a much longer-term privatization path and were encouraged by a shift in Congress toward more conservative control, their emergence was driven by capitalist constraints on policy makers in both parties. This time, though, policy makers were compelled by soaring inflation. Inflation weakened the value of the dollar, both at home and abroad, undermining purchasing power and causing "chaos in the international money markets." ${ }^{68}$ It also hurt government securities and hindered foreign investment. These trends led to a growing crisis of confidence in the investment environment in America for both domestic and foreign firms. At the twilight of the 1970s, it was apparent to many in government and the Federal Reserve that a collapse of the dollar was entirely plausible. Policy makers believed that such a collapse could lead to deep financial crisis and, possibly, the effort to remonetize gold, prospects that alarmed them. Even before Reagan entered the White House, politicians from across the party divide were keenly aware that the state had to strengthen the value of the dollar." ${ }^{69}$

By the late 1970s, even before Reagan took office, inflation had already spurred policy makers into action to rally around inflation-less growth. Wielding a theory of the causes of inflation that identified union wage gains as the main driver, both Democratic and Republican policy makers believed that unions were a key barrier to growth and competitiveness with America's foreign trading partners. Democratic policy makers under Carter moved to weaken labor, despite its longstanding role in the party coalition, as soon as they believed unions themselves were undermining capitalist growth. The eagerness of policy makers to discipline and weaken unions led to the strengthening of pension regulation under Reagan. New rules on union plans were one means among many used in the period to undermine labor leverage. Even though their purpose was part of a broader effort to weaken labor power, the rising financial regulatory burden on firms that administered DB plans inadvertently triggered the expansion of $401(\mathrm{k}) \mathrm{s}$.

An explanation of the cause of inflation, which pointed to organized labor as the main driver, was circulated at the highest levels of policy making under the Carter administration. As early as the late 1960s, policy makers agreed that weakening labor power was key to curbing inflation. Inflation: The Present Problem, an OECD report in 1970, made the case that union gains were the cause of inflation and OECD governments should adjust their policies to deal with it. ${ }^{70}$ In meeting minutes of

68. Michael Moffitt, The World's Money: International Banking from Bretton Woods to the Brink of Insolvency (New York: Simon \& Schuster, 1983), 196.

69. Ibid.

70. Ho-fung Hung and Daniel Thompson, "Money Supply, Class Power, and Inflation: Monetarism Reassessed," American Sociological Review 81, no. 3 (2016): 447-66. 
the Federal Reserve Open Market Committee in 1977, the committee of the Federal Reserve that writes the monetary policy, worries were raised that "business did not appear to be pressing as actively as they might to hold labor costs down, fearing the impact of strikes and assuming that inflation would continue." ${ }^{\prime 1}$ In April, committee members warned that the contract that was negotiated in the coal industry had the potential to make the matter even worse if it set a pattern in other contract negotiations. $^{72}$

By the time Democrat Paul Volcker became the Federal Reserve's chairman in August 1979, the rate of inflation had reached nearly 13 percent. Volcker's monetary policy was restrictionist. In the same year the Federal Reserve, with support from the State Department, made its first real effort to curb inflation, tightening the money supply as a means to counter rising consumer demand. Restricting money triggered increases in the interest rate, intentionally staggering the economy with the aim of ultimately reducing inflation. The administration and Volcker also used the Federal Reserve to impose mandatory credit controls on the economy, inducing a credit crunch to force the banks to stop lending. The first shock was explicitly intended to get firms to discipline their workforces, cutting where necessary and resisting labor demands for wage growth. ${ }^{73}$

After Reagan was elected, having not achieved the decreases in inflation that his initial shock aimed for, Volcker stayed on course. By 1982 Volcker said that in order to continue to put downward pressure on inflation, which had been dropping steadily since 1980, "progress will need to be reflected in moderation in the growth in nominal wages. The general indexes in worker compensation still show relatively little improvement." ${ }^{74}$ Although there was some disagreement within his staff and party, Reagan agreed with Volcker's course of action. On February 15, after a private meeting at the White House with the chair, Reagan said to the press corps, "I have confidence in the announced policies of the Federal Reserve Board. ... The administration and the Federal Reserve can help bring inflation and interest rates down faster by working together than working at cross-purposes." Reagan repeated this public vote of confidence several times over the next few years. ${ }^{75}$ Key business

71. Federal Reserve, "Record of Policy Actions of the Federal Open Market Committee: Meeting Held on August 16, 1977," Federal Reserve Bulletin, no. 915 (1977).

72. Federal Reserve, "Record of Policy Actions of the Federal Open Market Committee: Meeting Held on April, 18, 1978," Federal Reserve Bulletin, no. 470 (1978).

73. Moffitt, World's Money.

74. Paul A. Volcker, "Statement before the Joint Economic Committee of the U.S. Congress January 26, 1982, Statements to Congress," Federal Reserve Bulletin, no. 89 (1982).

75. Joseph B. Treaster, Paul Volcker: The Making of a Financial Legend (Hoboken, NJ: Wiley, 2004), 174-75. 
leaders on Wall Street were pleased with his resolve to weaken unions and break inflation and their support helped keep Volker in his position until $1987 .^{76}$

Reaganomics was not a sharp break but instead the continuation of this policy shift that started under Carter, which intended to spur growth and competitiveness within the economy at the expense of union wage gains. After all, a Democratic Congress under Carter hoisted an austerity program, with wage restraint as the core objective, onto the backs of the UAW members at Chrysler. ${ }^{77}$ Weakening unions, which would reduce inflation and increase productivity, was the centerpiece of the Reagan administration's plan for more flexible markets.

But Reagan's administration sought to push down wages indirectly; the administration only rarely directly interfered in contract negotiations. The administration's firing of more than 1 1,000 members of the Professional Air Traffic Controllers Organization (PATCO) is well known but was the exception in this regard. ${ }^{78}$ More commonly and much less publicly, the administration sought to remove any political or economic advantage that labor might have in negotiations with employers. In September 1981, according to Murray L. Weidenbaum, the first chairman of Reagan's Council of Economic Advisors, "we are not telling labor and management what to do. We are subjecting them to the fundamental force of market pressures." ${ }^{79}$ Supporting Volcker was a key dimension of this.

The less well known relationship between the Teamsters and the Reagan government is more typical of Reagan's labor policy than that of PATCO. The Teamsters were one of the more affluent and conservative unions and, like PATCO, the Teamsters had publicly supported Reagan's bid for the presidency. Despite their endorsement, the Teamsters lost 400,000 members from 1977 to 1983, one of the sharpest declines in union membership in US history to that point and were repeatedly targeted by Reagan's administration once he entered office and members of Congress. $^{80}$ The Teamsters' pension fund, the Central States Pension Fund, lay at the center of Reagan's effort to undermine the union's bargaining capacity. Middleclass unions, with better-paid workers, like PATCO and the Teamsters, were a concern because of their ability to drive up wages and inflation. PATCO's execution was swift and made easy because of the illegal status of its strike, but weakening the Teamsters required a more patient approach. In August 1981, after 35 witnesses

76. Ibid., 176.

77. Kim Moody, An Injury to All: The Decline of American Unionism (London: Verso, 1988).

78. Joseph A. McCartin, Collision Course: Ronald Reagan, the Air Traffic Controllers, and the Strike That Changed America (Oxford: Oxford University Press, 2011).

79. Leonard Silk, "Economic Scene: Reagan Goals and Labor," New York Times, September, 18, 1981 , D2. 80. Thomas Edsall, The New Politics of Inequality (New York: Norton, 1984). 
gave more than 1,000 pages of testimony, the Investigations Subcommittee of the Senate Governmental Affairs Committee issued a report saying that the Teamsters' Central States Pension Fund had not been regulated strongly enough by the Department of Labor. And just a matter of months after being nominated by Reagan, Donald L. Dotson, assistant secretary of labor for labor management relations, said the Department of Labor "had too much comradery" with unions under the Carter administration. Dotson argued that the Department of Labor's powers needed to mobilize more forcibly against unions like the Teamsters. ${ }^{81}$

Ratcheting up regulations on union pension funds was one tactic among many in the period used to weaken organized labor; they were a part of a much larger repertoire. Regulations were pursued by the administration, not to protect retiree income but rather to undermine union capacity and clout in negotiations with employers. By the end of July 1982, the Reagan administration was asking Congress to put new financial controls on the Teamsters' $\$ 3.5$ billion fund. Both Raymond Donovan, the labor secretary, and Roscoe L. Egger, Jr, the Internal Revenue Service commissioner, asked the oversight subcommittee of the House Ways and Means Committee for a higher excise tax and increased Labor Department powers to seek injunctions on fund trustees that invest in "prohibited transactions." ${ }^{82}$ The Teamsters' fund, as well as others in the building trades, had a history of investing in projects that used union labor. The passage of pension regulations is a key factor in the market-oriented shift in old-age security toward 401(k)s.

In 1974, the Employee Retirement Income Security Act (ERISA) fundamentally revised the rules of pensioning. ERISA regulates almost every aspect of private pensioning, such as plan information disclosure, termination insurance, transaction rules, funding requirements, and fiduciary responsibility. On the campaign trail, Reagan promised that he would repeal the law much to the support of unions like the Teamsters that were constrained by it, yet once he was elected he supported legislation that expanded its regulatory scope. Taken together, these regulations have concerned traditional DB plans to a far greater extent than DC plans. Although technically many of the rules cover all pension plans, simply by the structure of their design DC plans often went unaffected. ${ }^{83}$

81. Shirley Hobbs Schiebla, "Not Since Taft-Hartley Has Such a Crackdown on Union Power Loomed," Barron's National Business and Financial Weekly, October 26, 1981.

82. Robert L. Jackson, "New Financial Controls over Teamsters' Pension Fund," New York Times, July 27, 1982, B 12.

83. Robert Clark and Ann McDermed, The Choice of Pension Plans in a Changing Environment (Washington, DC: American Enterprise Institute, 1990); Edwin C. Hustead, "Trends in Retirement Income Plan Administrative Expenses," in Living with Defined Contribution Plans, ed. Olivia S. Mitchell and Sylvester J. Schieber (Philadelphia: University of Pennsylvania Press, 1998). 
Although the 1980s are widely recognized as a period of state-managed deregulation, that trend did not extend to pension legislation where the law's core provisions were strengthened and the agency responsible for overseeing it was pushed by politicians to take a more aggressive posture in its administration. Even in the early days of the Reagan revolution, Jeffrey Clayton, a conservative Mormon from Utah appointed by Reagan to the Pension and Welfare Benefit Program in the Department of Labor, the position in charge of enforcing ERISA, took a middle-of-theroad approach, saying, "We'll deregulate where prudent. But to protect plans from abuse, we have to be tougher in enforcing the meaningful provisions of ERISA." ${ }^{84}$

The result of the wave of new laws in the 20-year period following the passage of ERISA was an incremental increase in the administrative costs associated with operating a DB retirement plan up to 1996, when the legal regime was subject to deregulation under President Clinton. Though ratcheting up regulations was intended to constrain what unions could do with respect to their pension funds, rising administrative costs for DB plans were a parallel development.

Smaller plans disproportionately felt the regulatory burden relative to plans that covered larger numbers of beneficiaries. As shown in figure 3, costs for smaller plans, especially those operating as DB, increased dramatically in the 1980s—with the largest increase in administrative costs after the 1986 Tax Reform Act. Per capita costs decrease with more participants because of economies of scale. But the legislation included several requirements that were particularly burdensome for small firms operating a DB plan. In particular, the withdrawal liability established by Multiemployer Act in 1980 disproportionately affected small plans. According to business testimony at the Department of Labor, it "has a very negative impact on the adoption of multiemployer plans by new employers." ${ }^{85}$ And provisions aimed to reduce top-heavy plans in the tax reforms in both 1982 and 1986 also increased administrative costs for smaller plans to a larger degree. Top-heavy plans, identified in the 1982 act, are plans where more than 60 percent of the accounts or accrued benefits are attributable to employees at the top of the internal job ladder. These regulations drastically reduced incentives for small businesses to adopt or maintain DB plans. ${ }^{86}$

84. Diane Hal Gropper, “The Ordeal of Jeffrey Clayton," 1982, Social Security Department, 85-0036, box 1, unprocessed files, George Meany Memorial Archives, Silver Spring, MD (hereafter cited as GMMA).

85. Andrew H. Cox, "The Impact of ERISA and Related Legislation on the Development of Private Retirement Plans," Remarks at the Department of Labor ERISA Advisory Council on Employee Welfare and Pension Benefit Plans, March 15, 1984, AFL-CIO Occupational Safety, Health, and Social Security, 87-0011 box 10, GMMA.

86. Kelly Olsen and Jack VanDerhei, Defined Contribution Plan Dominance Grows across Sectors and Employer Sizes, while Mega Defined Benefit Plans Remain Strong: Where We Are and Where We Are Going, Special Report and Issue Brief no. 190 (Washington, DC: Employee Benefit Research Institite, 1997). 


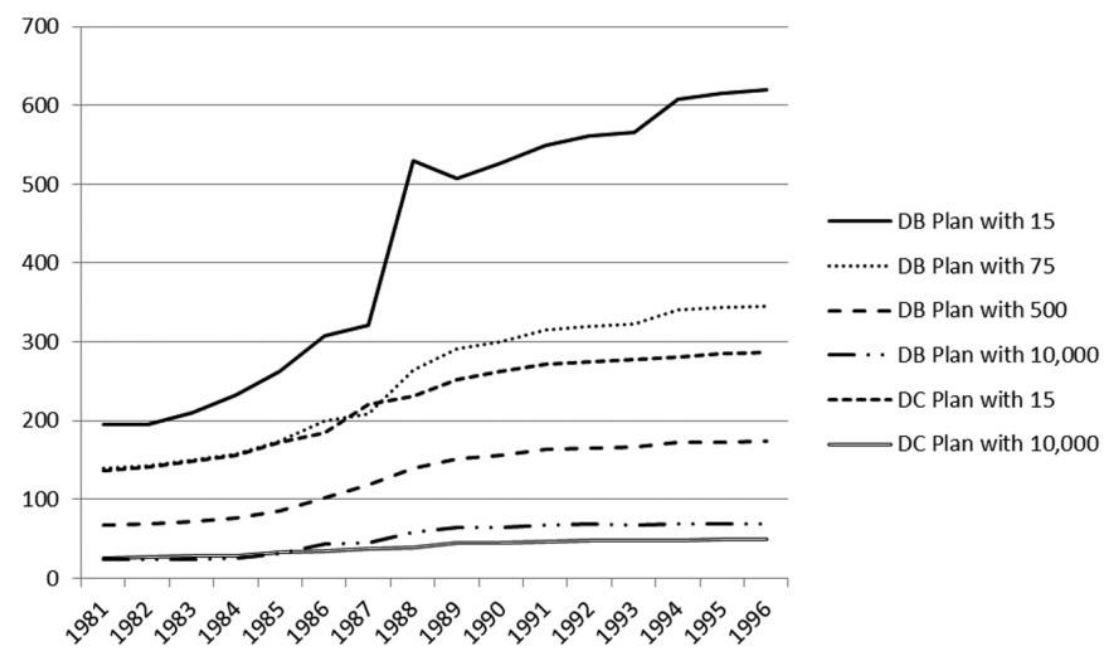

Figure 3. Annual per capita pension administration costs in 1996 dollars (Hustead 1998, 166-77)

By the end of the 1980s, businesses were expecting Congress to launch an allout assault on the tax-exempt status of retirement plans. In the words of a 1989 Business Week article, that "would kill employer-paid plans." Congress debated several reforms in the late 1980s: legislation that would make it harder for employers to engage in reversions, joint trustees on single-employer plans, increased taxation, and an age-discrimination regulation. As Howard C. Weizmann, executive director of the Association of Private Pension and Welfare Plans, noted, "what we're seeing is a battle for control of pension assets between labor, employers, and the government." ${ }^{87}$ The net result of this battle was fewer employer-sponsored plans-a somewhat unintended result of the growing institutional complexity of regulations and the growing administrative burden on a system that is entirely voluntary for employers to opt into or not. ${ }^{88}$

Contingencies in the period help explain why these rules resulted in a shift toward DC plans. It is now well known that shifts in the employment structure favored a large growth in service sector work in the 1970s and 1980s and a decline in manufacturing as a share of total employment. Goods-producing industries were already in decline by the time of the passage of ERISA in 1974. And the share of service industries, usually smaller, owner-run businesses that tended to employ younger, female, and part-time workforces, began to increase as early as the post-

87. Business Week, "The Power of Pension Funds," November 6, 1989, AFL-CIO Department of Legislation, 1994-0224 box 11, GMMA.

88. Cox, "Impact of ERISA." 


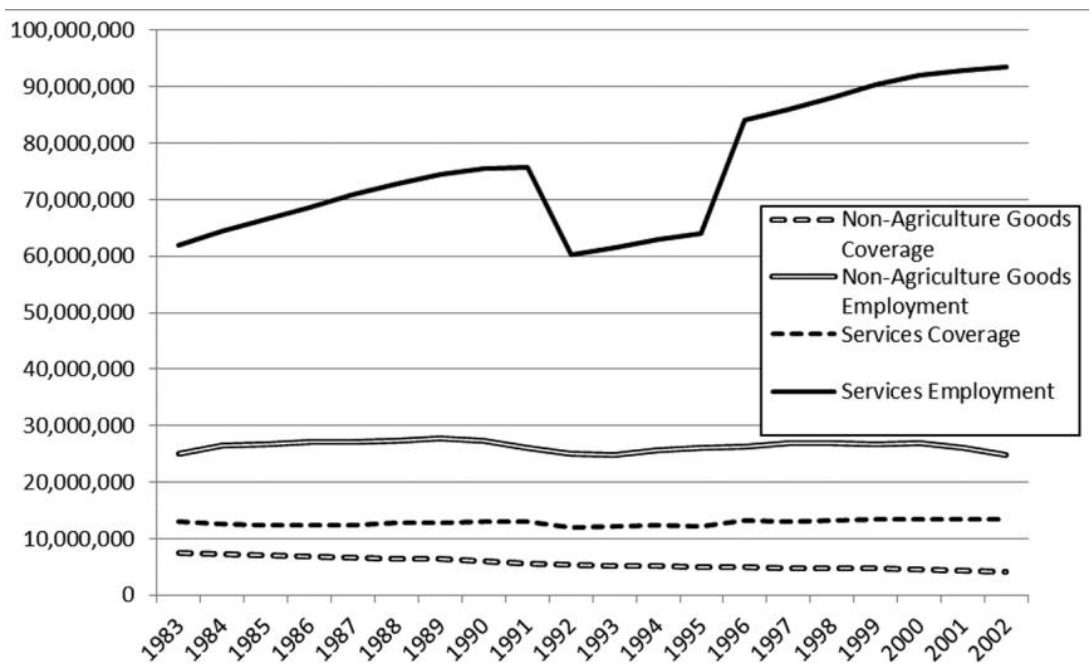

Figure 4. Sectoral employment and union coverage trends, 1983-2002. Author's calculations from the Current Population Survey (Barry T. Hirsch and David A. Macpherson, "Union Membership and Coverage Database from the Current Population Survey: Note," Industrial and Labor Relations Review 56, no. 2 [2003]: 349-54).

war period. Manufacturing jobs were once organized labor's stronghold. ${ }^{89}$ And as figure 4 shows, although union density in goods-producing firms declined over the period, from about 30 percent in 1983 to 16 percent in 2002, it was always higher than the density in the services. Figure 4 reports that, although services employment began to grow rapidly in 1983, unions were unable to organize a meaningful percentage of those new employees. Even in the goods-producing industries where unions had previously made historic gains, they faced absolute declines in worker coverage. Over the period of the 1980s and 1990s, across most sectors (with the public sector being the one area where DB plans endured), union density went into decline.

Is it possible that the regulations of the period ultimately did not matter and that firms would have chosen these DC plans regardless? Two points suggests that this explanation alone is incomplete. First, it fails to explain the timing. There is no substantive shift toward DC plans until the 1980s, long after the marked increase in services relative to the goods-producing sectors in the employment share. Although the growth in services accelerated in the 1970s, there had been a gradual

89. Michael Goldfield, The Decline of Organized Labor in the United States (Chicago: University of Chicago Press, 1987), 126. 
move of the economy in the direction of services since at least the 1950s. Second, if share of employment in manufacturing and services were all that mattered for plan adoption, then traditional plans should have never been dominant in the first place. From the postwar period on, services always accounted for a greater share of employment than goods-producing industries. Even in the beginning of the 1980s, more than 30 million more people worked in services than in the goods-producing sectors (see fig. 4). However, the dominance of this sector prior to the 1980s did not lead to the dominance of DC-type plans in the same period. In short, if sectoral trends alone explained the rise of DC plans, we should have seen them much sooner and they should have always been dominant.

Though characterized by policy makers as the chief source of inflation, labor unions were already in decline. Union density in the 1970s fell by a fifth, from 26 percent to 20 percent of the workforce. In the 1980s, it fell another 5.4 percent. Researchers believe that factors like the shift toward services account for 20 percent to 60 percent of the decrease in union density since the postwar period. Even with no change in the absolute number of union members, union density would have declined if unions had remained strong in the goods-producing sectors of the economy that were shrinking. ${ }^{90}$ But union decline in the period was not driven exclusively by these changes; unions were also weakened in the sectors where they were strongest, such as manufacturing. ${ }^{91}$

Unions were a key force in both the establishment and spread of the DB pension system. Once collective bargaining was made mandatory by the Supreme Court in 1947, all unions had to do was pressure employers into agreements. However, when union strength began to wane and employers were free to run their businesses without a representative voice for workers, firms had less reason to be concerned with which plan was best for their employees. In a context of weakening union strength, employers in the new sectors that were being disproportionately hit by administrative costs were free to ignore union demands for DB plans. As a result, firms in the emergent sectors of the economy increasingly adopted DC plans and 401 (k)s. By 1993, just 21 percent of all contributions to DC plans were provided by employers with unionized employees—79 percent were employers with nonunion workforces. ${ }^{92}$ But a sole analytic focus on decline in union density leads to explanatory

90. Dan Clawson and Mary Ann Clawson, "What Happened to the US Labor Movement? Union Decline and Renewal," Annual Review of Sociology 25 (1999): 95-119.

91. Bruce Western, Between Class and Market: Postwar Unionization in the Capitalist Democracies (Princeton, NJ: Princeton University Press, 1997).

92. Employee Benefit Research Institute, Defined Contribution Plan Dominance Grows across Sectors and Employer Sizes, while Mega Defined Benefit Plans Remain Strong: Where We Are and Where We Are Going, EBRI Issue Policy Brief no. 190 (Washington, DC: Employee Benefit Research Institute, 1997). 


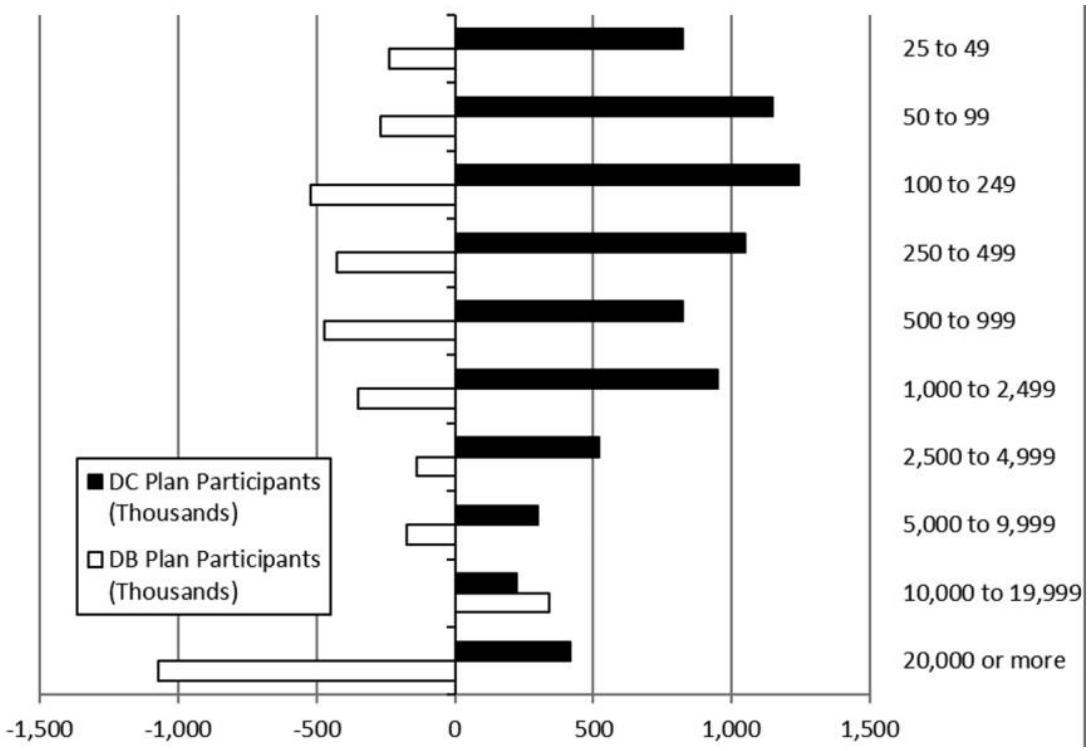

Figure 5. Net change in participants in primary plan by plan size, 1985-1993 (Employee Benefits Research Institute 2002; data drawn from Form 5500 filed with the Internal Revenue Service).

problems similar to those solely focusing on shifts in employment. Had union density been the only factor that mattered to plan adoption again we would not be able to explain the timing. Union density in America has been in decline since the mid1950s. And during that decade and the next, traditional plans were becoming more popular rather than less popular.

Instead, regulatory costs augmented DB adoption disincentives for smaller firms. Those smaller firms had more capacity in the emergent nonunion sectors and were able to avoid these costs by adopting DC plans or none at all (see fig. 5). A spate of statistical studies in the 1980s and the 1990s by economists tried to identify the core characteristics of the new companies that were adopting DC plans. There is consensus among researchers that three features of the firm were the most important determinants for the kind of pension plans that were adopted by businesses: employees of large firms are more likely to be offered a traditional pension plan than workers at small firms, the shift from manufacturing to services decreased participation in DB plans, and deunionization in these sectors was a key factor for the fall in DB coverage. ${ }^{93}$ Empirical studies have shown that the loss of employment in

93. Randy Hodson, "Modeling the Effects of Industrial Structure on Wages and Benefits," Work and Occupations 13, no. 4 (1986): 185-204; David E. Bloom and Richard Freeman, "The Fall in Private Pension Coverage in the US," American Economic Review 82, no. 2 (1992): 539-45; Douglas L. Kruse, "Pension Sub- 
larger, unionized good-producing sectors, where DB plans had historically prevailed, can explain nearly half of the shift. ${ }^{94}$ In short, traditional plans in large unionized firms in the goods-producing sector lost a significant portion of the total pension plan and participant share to DC plans in smaller, nonunion firms in the service sector.

\section{FROM ECONOMIC CRISIS TO RETIREMENT CRISIS}

Given these glacial shifts in America's retirement system since the New Deal period, what have been the main effects on the majority of Americans? According to the Government Accountability Office, half of all households have nothing saved at all. ${ }^{95}$ And fewer people have some kind of retirement plan. In 2001, 60 percent of the working population had a retirement plan; that figure has now dropped to 50 percent. Of the half that do, more than 70 percent have a risky 401 (k) savings plan. The average household approaching retirement with a $40 \mathrm{l}(\mathrm{k})$ has barely enough to live on for two years, and two thirds of workers with a $401(\mathrm{k})$ are not contributing any of their income to it. ${ }^{96}$ The reason is not a subject of great mystery. Even the US government finds that the bottom 80 percent of workers struggle to save because wages have stagnated since the 1970s. ${ }^{97}$ The outcome of this marketization of old-age income security has been to further fortify and deepen the inequality between the working class and the wealthy in America, not only making retirement itself more insecure but also casting its existence as a stage of life into doubt for many people.

This pension marketization was driven by political responses to perceived crises in capitalism. Policy makers find themselves compelled to realize two sometimes contradictory objectives when they govern. Most fundamentally, they need to encourage and facilitate capitalist accumulation and economic growth. But there are constraints on how they do this. They need to do so in a way that is seen as legitimate by those they govern. This imperative to maintain and encourage accumulation is a structural condition; its persistent influence endures across the varieties of capitalist democracy despite which particular individuals or groups hold sway in policy mak-

stitution in the 1980s: Why the Shift toward Defined Contribution?," Industrial Relations 34, no. 2 (1995): 218-41.

94. Richard A. Ippolito, "Toward Explaining the Growth of Defined Contribution Plans," Industrial Relations 34, no. 1 (1995): 1-20.

95. Government Accountability Office, Retirement Security: Most Households Approaching Retirement Have Low Savings, GAO-15-419 (Washington, DC: Government Accountability Office, 2015).

96. Ben Steverman, “Two-Thirds of Americans Aren't Putting Money in Their 401 (k)," Bloomberg Business, February 21, 2017.

97. Government Accountability Office, The Nation's Retirement System: A Comprehensive Re-evaluation Is Needed to Better Promote Future Retirement Security (Washington, DC: Government Accountability Office, 2017). 
ing circles or even in the political ideology and positions of the policy makers themselves. Simply put, not governing for capitalism, which could negatively affect the economy, runs a high risk of being voted out of office for every politician in a capitalist democracy.

Such a structuralist view only accounts for policy makers' general motivation to encourage capitalist growth. It does not, however, tell us why policy makers try to encourage growth in the particular ways they do or the effects of their interventions once they make them. I have shown that the structural imperative constrains policy makers' choices between some range of options that they believe will facilitate accumulation, but contingent historical factors both select from within that range and explain how policy decisions spur welfare change. Inequality in American retirement income and security was deepened along a structurally contingent path of causation. It was neither a project intentionally installed nor the product of lawlike structural forces but was instead made unintentionally by policy makers promoting capitalist growth.

Leading institutionalists, such as Jacob Hacker and Paul Pierson, have gestured toward the importance of taking capitalism more seriously in studies of policy change, suggesting that "the pressure to protect business interests [that politicians encounter when they govern] is generated automatically and apolitically" even if they have left their theories of the welfare state unrevised. ${ }^{98}$ Others, like Wolfgang Streeck, have already shifted their attention to the ways capitalism constrains institutional change more broadly across institutionally differentiated contexts. ${ }^{99}$ For instance, Pepper Culpepper and Raphael Reinke recently showed how both the automatic and strategic use of structural power on the part of banks in the years following the 2008 financial collapse explains variation in bailout design between the United States, the United Kingdom, France, and Germany. ${ }^{100}$ Similarly, this article shows that the capitalist context imposes deep constraints on the ways in which much of policy is made in advanced democratic countries. To ignore them is to miss what is so fundamental about capitalist democracy itself.

98. Hacker and Pierson, "Business Power," 281.

99. Streeck, Buying Time.

100. Culpepper and Reinke, "Structural Power." 